\title{
Az Amerikai Egyesült Államok népegészségügyi rendszere és egészségfejlesztéssel foglalkozó szervezetei
}

\author{
The public health system and health promotion organizations \\ of the United States of America
}

\author{
Szerzők: Túri Gergő $\bowtie$, Terebessy András ${ }^{a, b}$, Horváth Krisztián ${ }^{a, c}$ \\ a: Országos Közegészségügyi Intézet, b: Semmelweis Egyetem, c: Budapesti Corvinus Egyetem
}

Beküldve: 2018. 03. 09.

doi: $10.24365 /$ ef.v59i2.256

\begin{abstract}
Összefoglaló: A cikkben az Amerikai Egyesült Államok népegészségügyi rendszerének és egészségfejlesztéssel foglalkozó szervezeteinek bemutatásán keresztül tanulságokat fogalmazunk meg a hazai egészségfejlesztési hálózat lehetséges továbbfejlesztési irányainak meghatározása érdekében. Röviden ismertetjük az egyes közigazgatási szintek és szervezetek főbb szerepét a népegészségügyi rendszerben, bemutatjuk a népegészségügyi rendszer kialakulását és működését befolyásoló releváns stratégiákat és jogszabályokat, valamint összefoglaljuk a szövetségi, tagállami és közösségi szinten működő szervezetek feladatait és tevékenységeit. Az Amerikai Egyesült Államok népegészségügyi rendszerét kevésbé jellemzi az erős hierarchikus struktúra, a szubszidiaritás elve érvényesül: minden funkciót és feladatot a legalacsonyabb működési szinten igyekeznek ellátni, azonban a szövetségi kormányzattól is kapnak szakmai és anyagi támogatást, ha szükséges. A közösségi szinten működő helyi egészségosztályok tagállamonként eltérő múködési modellje alakult ki, azonban fontos tanulság az, hogy e szervezetek szolgáltatási portfóliója, valamint humán erőforrása igazodik az ellátott populáció nagyságához. A helyi egészségosztályok munkáját támogatja egy szakmai ernyőszervezet, amely módszertani központként szolgáltatási protokollokat készít, elősegítve a népegészségügyi szolgáltatások minőségének fejlesztését és egységesítését. Számos szervezet végez széles körű népegészségügyi kutatásokat, a Nemzeti Egészségügyi Intézetek tagintézményei egy-egy egészségprobléma területére specializálódtak.

Kulcsszavak: népegészségügyi rendszer; egészségfejlesztés; Amerikai Egyesült Államok
\end{abstract}

Summary: In the article we present the lessons learned from studying the public health system and health promotion organizations of the United States of America, to determine the possible directions for further development of the Hungarian health promotion network. We briefly describe the main roles of the public administration levels and organizations in the public health system, present relevant strategies and legislation affecting the development and functioning of the public health system, and summarize the tasks and activities of organizations at federal, state and community level. The public health system in the United States is less characterized by a strong hierarchical structure, instead focuses on the principle of subsidiarity: all functions and tasks are carried out at the lowest possible operating level, however they also receive professional and financial support from the federal goverment, if need arises. Different operational models of the Local Health Departments (operating at community level) have emerged, but an important lesson is that the service portfolio and human resources of these organizations reflects the size of the population. The work of the Local Health Departments is supported by a professional umbrella organization, that serves as a methodological centre for service protocols, promoting 
the development and standardization of the quality of public health services. Many organizations carry out extensive public health research, and the departments of National Institutes of Health specializes on different disciplines of health.

Keywords: public health system; health promotion; United States of America

\section{AZ EGYES KÖZIGAZGATÁSI SZINTEK ÉS FŐBB SZERVEZETEK SZEREPE A NÉPEGÉSZSÉGÜGYI RENDSZERBEN}

Az Amerikai Egyesült Államok egészségügyi rendszerében a különböző szintű kormányzatok, biztosítók és szolgáltatók szorosan együttmúködnek egymással. ${ }^{1} \mathrm{Az}$ egészségügyi szolgáltatásokhoz való hozzáférés egyrészt a magánbiztositóknál (Private Insurers) kötött biztositáson (Private insurance) keresztül érhető el, másrészt a szövetségi kormányzat (Federal Government) és a tagállami kormány- zat (State Government) által finanszírozott kormányzati biztositási programokon (Government insurance programs) keresztül [1. ábra].

Az Amerikai Egyesült Államokban három közigazgatási szinten azonosíthatók népegészségügyi szervezetek. A szövetségi szinten múködő Egészségügyi és Humán Szolgáltatások Minisztériuma (Department of Health and Human Services) felelős a népegészségüggyel kapcsolatos szakpolitikák és prioritások megfogalmazásáért, valamint számos kutatóintézetet, illetve tagállami és közösségi szinten múködő népegészségügyi szervezetet finanszíroz. ${ }^{2}$

1. ábra: Az egészségfejlesztésben szerepet játszó szervezetek az Amerikai Egyesült Államok népegészségügyi rendszerében

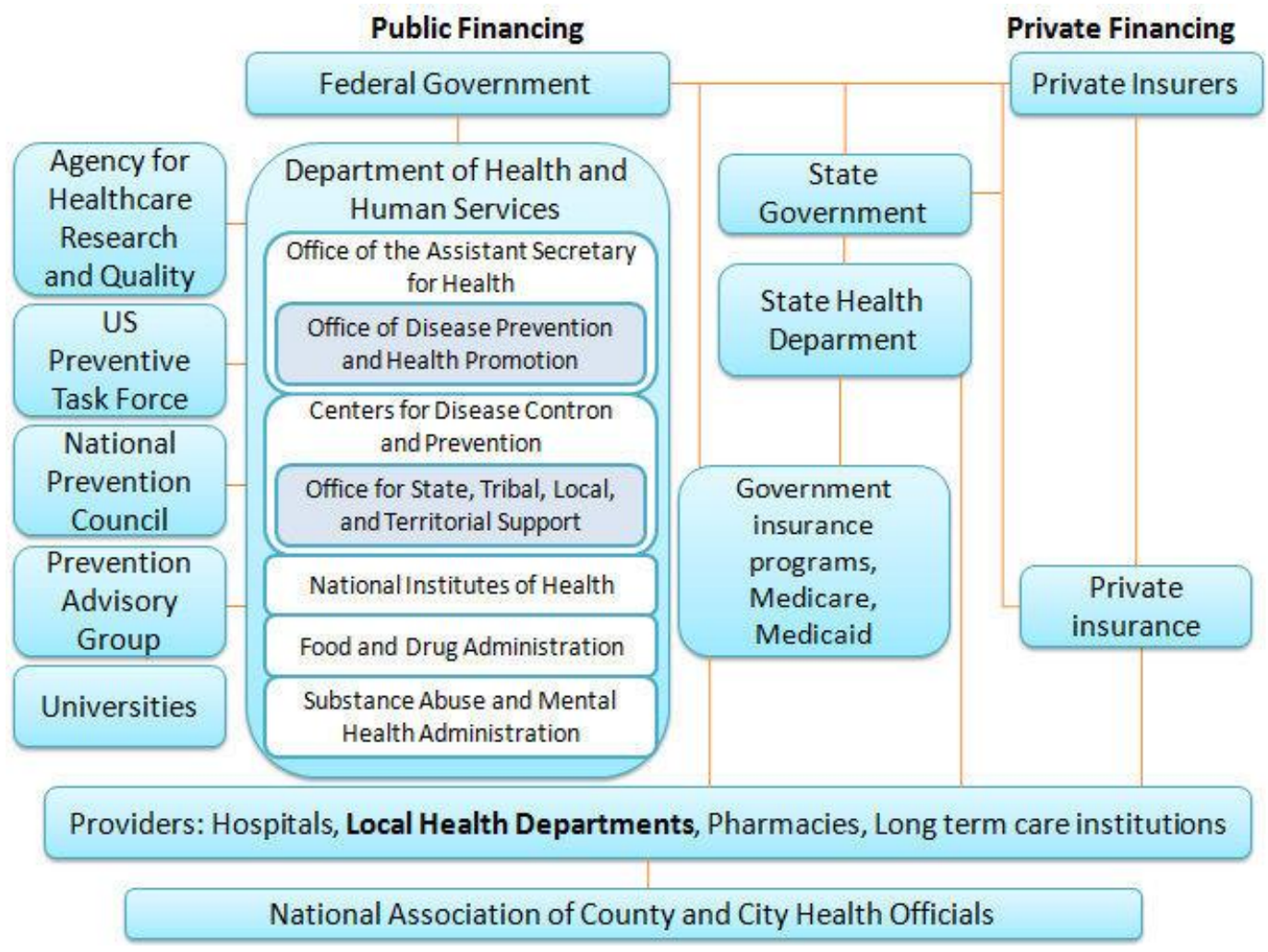

Forrás: Mossialos E et al. (2015) és saját kiegészítések ${ }^{3}$ 
Az Egészségügyi Államtitkári Hivatal (Office of the Assistant Secretary for Health), valamint e szervezet részeként múködő Betegségmegelőzési és Egészségfejlesztési Hivatal (Office of Disease Prevention and Health Promotion) felelős a minisztérium által nyújtott szolgáltatások koordinálásért. A minisztérium munkáját számos további nemzeti intézet segíti: a betegség-ellenőrzési és -megelözési központok (Centers for Disease Control and Prevention) feladata bizonyítékokon alapuló programok fejlesztése, népegészségügyi elemzések készítése, a lakosság egészségét veszélyeztetők problémák megelőzése, illetve a kialakult veszélyek hatékony és gyors kezelése. ${ }^{3} \mathrm{~A}$ központok egyik tagszervezeteként múködő Állami, Törzsi, Helyi és Területi Támogatási Hivatal (Office for State, Tribal, Local, and Territorial Support) feladata az állami és közösségi népegészségügyi szervezetek teljesítményének és kapacitásainak fejlesztése, támogatása. Az Élelmiszer- és Gyógyszerügyi Hatóság (Food and Drug Administration) feladata többek között az egészséggel kapcsolatba hozható termékek innovációjának támogatása. A Nemzeti Egészségügyi Intézetek (National Institutes of Health) 27 tagintézményének feladata különböző, az egészséget befolyásoló tényezők valamint betegségek megelőzésének és kezelésének tudományos vizsgálata. A Kábitószerrel Való Visszaélés és Mentális Egészségügyi Szolgáltatások Hatóság (Substance Abuse and Mental Health Services Administration) programokat és akcióterveket fejleszt a mentális egészség és szerhasználat témakörökben. Az Egészségügyi Kutatási és Minőségügyi Ügynökség (Agency for Healthcare Research and Quality) feladata az egészségügyi ellátási rendszer vizsgálata és elemzése. Szakmai tanácsadó szervezet az Amerikai Preventív Szolgáltatások Munkacsoportja (US Preventive Service Task Force), a Nemzeti Megelőzési Tanács (National Prevention Council) és a Prevenciós Tanácsadó Testület (Prevention Advisory Group). A Megyei és Városi Egészség-tisztviselők Nemzeti Szövetségének (National Association of County and City Health Officials) feladata szolgáltatásprotokollok, programok és képzési anyagok fejlesztése a közösségi szinten múködő, népegészségügyi szolgáltatásokat nyújtó szervezetek számára. ${ }^{4}$

Tagállami szinten az állami egészségügyi minisztériumok (State Health Departments) feladata egyrészt az egészséggel kapcsolatos termékekre és szolgáltatásokra vonatkozó jogszabályalkotás, másrészt feladatuk a szakemberek képzésének támogatása, valamint a közösségi szinten működő népegészségügyi szolgáltatók finanszírozása. Közösségi szinten a helyi egészségosztályok (Local Health Departments) felelősek a különböző népegészségügyi szolgáltatások biztosításáért.

\section{AZ INTÉZMÉNYRENDSZER MŰKÖDÉSÉT MEGHA- TÁROZÓ JOGSZABÁLYOK ÉS STRATÉGIÁKK}

Bár az Amerikai Egyesült Államokban nincs általános egészségbiztosítás, az 1965-től múködő Medicare és Medicaid programok révén bizonyos társadalmi csoportok részesülhetnek a szövetségi kormány által finanszírozott egészbiztosításban. ${ }^{5} \mathrm{~A}$ Medicare program azoknak a 65 éven felüli állampolgároknak nyújt biztosítást, akik korábban fizettek jövedelemadót az országban. A program keretében meghatározott szolgáltatások és gyógyszerek finanszírozását támogatja részben vagy teljesen a szövetségi kormány. A Medicaid program hátrányos helyzetű társadalmi csoportok számára nyújt egészségbiztosítást, főként olyanoknak, akik alacsony jövedelme nem teszi lehetővé a különböző egészségügyi szolgáltatások igénybevételét.

A 2010-ben elfogadott törvény a megfizethetó ellátásról (Affordable Care Act) komoly mértékben növelte az egészségügyi szolgáltatásokhoz való hozzáférést, mivel kiterjesztette azok körét, akik igénybe vehetik a meglévő állami programokat. ${ }^{6}$ Ezenkívül az alacsony jövedelmű egyének és a kisvállalkozások számára pénzügyi hitelt is nyújt annak érdekében, hogy egészségbiztositást vásárolhassanak. A törvény hatására mintegy 23 millió olyan állampolgár vehet igénybe szolgáltatásokat, akiknek korábban nem volt egészségbiztosítása. A törvény előirta továbbá egy Prevenciós és Népegészségügyi Alap (Prevention and Public Health Fund) létrehozását, amiből a népegészségügyi rendszer fejlesztését és egészségfejlesztési programok megvalósítását támogatják.

A 2011-ben elfogadott Nemzeti prevenciós stratégia (National Prevention Strategy) olyan megelőzésorientált társadalmat vizionál, amelyben minden ágazatban elismerik az egyének, a családok és a társadalom egészségének értékét, és együtt dolgoznak a jobb egészség megteremtése érdekében. ${ }^{7}$ A stratégia négy fő célt fogalmaz meg: egészséges és biztonságos közösségi környezet biztosítása, klinikai 
és közösségi megelőző szolgáltatások biztosítása, a közösségek felhatalmazása és képességeinek fejlesztése, az egészségegyenlőtlenségek csökkentése. A stratégia hét prioritása, fókuszterülete az alábbi: dohányzásmentes élet, a kábítószer-használat és a túlzott alkoholfogyasztás megelőzése, egészséges táplálkozás, fizikailag aktív életmód, a sérülések és az erőszak megelőzése, reproduktív és szexuális egészség, mentális és érzelmi jóllét. A stratégiában a prioritásokhoz bizonyítékokon alapuló ajánlások kapcsolódnak.

\section{SZÖVETSÉGI SZINTEN MŰKÖDŐ SZERVEZETEK}

\section{Minisztérium}

Az Egészségügyi és Humán Szolgáltatások Minisztériuma felelős a népegészségüggyel kapcsolatos szakpolitikák és célok, valamint standardok megfogalmazásáért. ${ }^{8} \mathrm{~A}$ népegészségügyi célok és prioritások kialakításába bevonja az állami és helyi kormányzati szereplőket és egyéb releváns szakértőket. A minisztérium finanszíroz számos, az egészséggel kapcsolatos kutatást és kutatóintézetet, valamint felsőoktatási intézményt. A szervezet feladata továbbá annak biztosítása, hogy az állami és helyi szintű kormányzati egységek megfelelő kapacitásokkal rendelkezzenek a szükséges népegészségügyi szolgáltatások nyújtásához. Amennyiben egynél több államban tűnik fel olyan probléma, amely nagymértékben veszélyezteti a lakosság egészségét, illetve ha a veszély elhárítására nincs megfelelő humán erőforrása egy államnak, akkor a minisztérium jogosult cselekedni a probléma elhárítása érdekében. Mindezeken túl a minisztérium támogatja azoknak a tudományos és technikai eszközöknek a fejlesztését, amelyekkel növelni lehet a népegészségügyi infrastruktúra hatékonyságát valamennyi kormányzati szinten.

\section{Nemzeti szervezetek}

Az Egészségügyi Államtitkár Hivatala felelős az Egészségügyi és Humán Szolgáltatások Minisztériuma által nyújtott szolgáltatások koordinálásáért, valamint javaslatok megfogalmazásáért a népegészségügyi területen. Az Egészségügyi Államtitkár Hivatala 12 szervezeten keresztül látja el feladatait, ezek közül fontos népegészségügyi szereplőként azonositható a Betegségmegelőzési és Egészségfejlesztési Hivatal. A hivatal fogalmazza meg a nemzeti egészségcélokat és koordinálja a minisztérium által biztosított szolgáltatásokat a betegségmegelőzés, az egészségfejlesztés, a megelőző egészségügyi szolgáltatások, valamint az információszolgáltatás és oktatás területén. A szervezet feladata továbbá, hogy az állami és privát szolgáltatásokat összehangolja a nemzet egészségének javítása érdekében. A hivatal munkatársai koordinálják az USA egyik legfontosabb, preventív szakmai irányelveket kidolgozó szervezetét, az Amerikai Preventív Szolgáltatások Munkacsoportját.

A Betegség-ellenőrzési és Megelözési Központ az USA vezető népegészségügyi szervezete, amelynek részét képezi számos kutatóintézet. Fő célja a lakosság egészségi állapotának javítása és biztonságának megőrzése, amely célt betegség ellenőrzési és megelőzési valamint baleset és rokkantság-megelőzési feladatok végzésével lát el. Fókuszában a kiemelt életmódi és más kockázati tényezők és az egészségfejlesztés áll. A nem fertőző betegségek területén az elhízás és a cukorbetegség emelhető ki, mint fő terület. A központ feladata bizonyítékokon alapuló népegészségügyi programok fejlesztése és értékelése, népegészségügyi elemzések készítése, epidemiológiai kutatások végzése és vészhelyzet esetén beavatkozás, valamint feladata a népegészségügyi humán erőforrás kapacitásainak fejlesztése, a népegészségügyi szakemberek folyamatos továbbképzése.

Az Állami, Törzsi, Helyi és Területi Támogatási Hivatalt a Betegségellenőrzési és Megelőzési Központ részeként hozták létre 2010-ben, és feladata az amerikai népegészségügyi rendszer teljesítményének, kapacitásának fejlesztése. A hivatal a helyi egészségosztályokat tekinti a megelözés elsődleges szereplőinek, ezért nemzeti népegészségügyi akkreditációs programot indítottak, amelyet a több mint 3000 helyi egészségosztály használhat múködésének folyamatos javitására. A népegészségügy legfontosabb kihívásainak megértése és kezelése érdekében a hivatal szorosan együttműködik az állami, törzsi, helyi és területi szervezetekkel és ezek alapján javaslatokat fogalmaz meg. A hivatal által megfogalmazott első ilyen ajánlás a Betegségellenőrzési és Megelőzési Központ által nyújtott technikai segítségnyújtás fejlesztésére vonatkozott, melynek eredményeképpen ma már magas szintű képzés, tájékoztatás és 
támogatást érhető el a központnál a helyi egészségosztályok vezetői számára.

Az Egészségügyi Kutatási és Minőségügyi Ügynökség legfontosabb feladata az amerikai egészségügyi ellátórendszer vizsgálata illetve támogatása annak érdekében, hogy a rendszer biztonságosabb legyen és a szolgáltatások minőségét javítani lehessen. Az ügynökség fő célja az egészségügyi ellátórendszer fejlesztéséhez szükséges ismeretek, eszközök és adatok gyűjtése és rendszerezése annak érdekében, hogy segítse az egészségügyi szakembereket és a döntéshozókat a tájékozott döntések meghozatalában. Ennek érdekében, többek között képzéseket valósítanak meg, hogy a kutatási eredmények átültethetők legyenek a mindennapi gyakorlatba. Emellett a szervezet adatokat is szolgáltat az egészségbiztosítóknak és egészségügyi ellátóknak, valamint a döntéshozóknak.

Az Élelmiszer-és Gyógyszerügyi Hatóság feladata az élelmiszerek biztonságának, a gyógyszeripari termékeknek (humán és állategészségügyi készítmények, oltóanyagok, egyéb biológiai termékek) a vizsgálata, valamint az orvosi eszközök forgalomba hozatalának engedélyezése. A szervezet feladata továbbá az egészséggel kapcsolatba hozható termékek innovációjának elősegítése és a dohánytermékek szabályozása.

A Nemzeti Egészségügyi Intézetek az USA fő kutatóintézeteit tömörítő szervezet, amelynek 27 tagja van. ${ }^{9}$ A szervezet kiemelt célja a tudományos kutatások végzése és azok eredményeinek elterjesztése az egészség megóvása és fejlesztése érdekében. Az intézetek ezért folyamatosan fejlesztik, fenntartják és megújítják azokat a személyi és tárgyi erőforrásokat, amelyek biztosítják az ország képességét a betegségek megelőzésére és kezelésére; bővítik az orvosi és kapcsolódó tudományok tudásbázisát és támogatják a tudományos integritást, a nyilvános elszámoltathatóságot és a társadalmi felelősségvállalást. A 27 tagintézmény közül példaként kiemelve a Nemzeti Onkológiai Intézet (National Cancer Institute) a daganatos betegségek megelőzésével és kezelésével kapcsolatban végez kutatásokat és képzéseket, a Nemzeti Öregedéskutató Intézet (National Institute of Aging) kutatásokat végez az öregedés folyamatának biomedikális, társadalmi és magatartási aspektusainak megismerése érdekében. A Nemzeti Alkoholártalom- és Alkoholizmuskutató Intézet (National Institute on Alcohol Abuse and Alcoholism) az alkoholizmus kialakulásának megelőzése, valamint kezelése témában végez kutatásokat és vizsgálja az alkoholizmussal kapcsolatos problémák egészségi, társadalmi és gazdasági aspektusait. A Nemzeti Környezeti Tudományok Intézete (National Institute of Enviromental Sciences) kutatásokat végez annak megismerése érdekében, hogyan befolyásolják a környezeti tényezők az emberek egészségét. A Nemzeti Kisebbségi Egészség- és Egészségegyenlötlenség-kutató Intézet (National Institute of Minority Health and Health Disparities) kutatásokat végez a kisebbségek egészségének fejlesztése és az egészségegyenlőtlenségek csökkentése érdekében, valamint programokat fejleszt, terjeszt, képzéseket végez és együttmúködéseket alakít a témában érdekelt szervezetek körében. A Nemzeti Orvosi Könyvtár (National Library of Medicine) gyüjti, rendszerezi és elérhetővé teszi a tudományos kutatások eredményeit a kutatók, a szakemberek és a lakosság számára.

A Kábitószerrel Való Visszaélés és Mentális Egészségügyi Szolgáltatások Hatósága célja a lakosság mentális állapotának fejlesztése. Mindezt elsősorban programok és akciók, stratégiai kezdeményezések segítségével érik el, amelyek lehetőséget adnak a mentális problémákkal küzdő, illetve szerhasználó emberek számára. A programok támogatják a mentális problémákkal küzdők családjait is, más kezdeményezéseik támogató közösségeket építenek, egyes esetekben pedig segítik a közösségi ellátások megszervezését.

\section{Szakmai és tanácsadó szervezetek}

\section{Az Amerikai Preventív Szolgáltatások Munkacso-} portja független szakértőkből áll, fő feladata bizonyítékokon alapuló ajánlások megfogalmazása. A munkacsoport ajánlásai különböző preventív szolgáltatásokra vonatkoznak, és minden ajánlást publikálnak és nyilvánosan elérhetővé tesznek. A szervezet ajánlásai a meglévő szakmai bizonyítékok szigorú felülvizsgálatán alapulnak, és arra szolgálnak, hogy segítsék a szakemberek döntését azzal kapcsolatban, hogy egy megelőző szolgáltatást ajánljanak-e egy populáció tagjai számára vagy sem. A munkacsoport minden ajánlást osztályoz a bizonyítékok ereje és a szolgáltatás előnyeinek és hátrányainak figyelembevétele alapján.

A Nemzeti Megelözési Tanács 20 szövetségi kormányzati szervezet tisztségviselőiből áll, és aktív szerepet vállalt a Nemzeti prevenciós stratégia 
kialakításában. A stratégia elfogadását követően a tanács kiadta a Nemzeti prevenciós stratégia cselekvési tervét, amely interszektoriális akciókat fogalmazott meg a kormányzati szervezetek számára a lakosság egészségének és jóllétének fejlesztése érdekében. A tanács minden évben jelentést nyújt be az elnöknek és a kongresszusnak a stratégiában meghatározott célok elérése érdekében tett intézkedésekről.

A Prevenciós Tanácsadó Testület feladata a Nemzeti prevenciós stratégia megvalósításának támogatása. A testület ajánlásokkal, szakpolitikai javaslatok megfogalmazásával támogatja a Nemzeti Megelőzési Tanács munkáját, valamint támogatja a tanács és a különböző kormányzati, magán- és civil szervezetek együttmüködését, partnerségek kialakítását.

A Megyei és Városi Egészség-tisztviselők Nemzeti Szövetsége a közösségi szinten müködő helyi egészségosztályok ernyőszervezete. Feladata olyan, bizonyítékokon alapuló programok, módszertanok és szolgáltatási protokollok fejlesztése, amelyeket a közösségi szinten múködő szervezetek, különösképpen a helyi egészségosztályok munkatársai mindennapi munkájuk során alkalmazni tudnak. A szövetség honlapján a regisztrált felhasználók részére számos témában érhetők el protokollok, irányelvek, elemzések, prezentációk, esettanulmányok, képzési anyagok. A szervezet emellett szerepet vállal a népegészségügyi szakemberek képzésében, konferenciákat szervez, programokat finanszíroz, és széles körü együttmüködést és partnerséget alakít a helyi és nemzeti szervezetekkel.

\section{Egyetemek}

Az országban több száz népegészségügyi képzést nyújtanak számos egyetemen, ahol népegészségügyi kutatásokat végeznek és szakértőket képeznek. A legrangosabb egyetemek közül a Harvardi T.H Chan Népegészségügyi Iskola (Harvard T.H. Chan School of Public Health), a John Hopkins Bloomberg Népegészségügyi Iskola (John Hopkins Bloombert School of Public Health), Yale Egyetem (Yale University), a Stanford Egyetem (Stanford University), a Columbia Egyetem (Columbia University) és a Michigan Egyetem (University of Michigan) nyújt népegészségügyi témájú képzéseket.

\section{TAGÁLLAMI SZINTEN MŰKÖDŐ SZERVEZETEK}

Az 51 tagállamban múködő állami egészségügyi minisztériumok feladata egyrészt az egészséggel kapcsolatos fogyasztási cikkekkel, szolgáltatásokkal kapcsolatos jogszabályalkotás, továbbá a fertőző betegségek felügyelete, ellenőrzése, ennek érdekében laboratórium múködtetése [2. ábra].

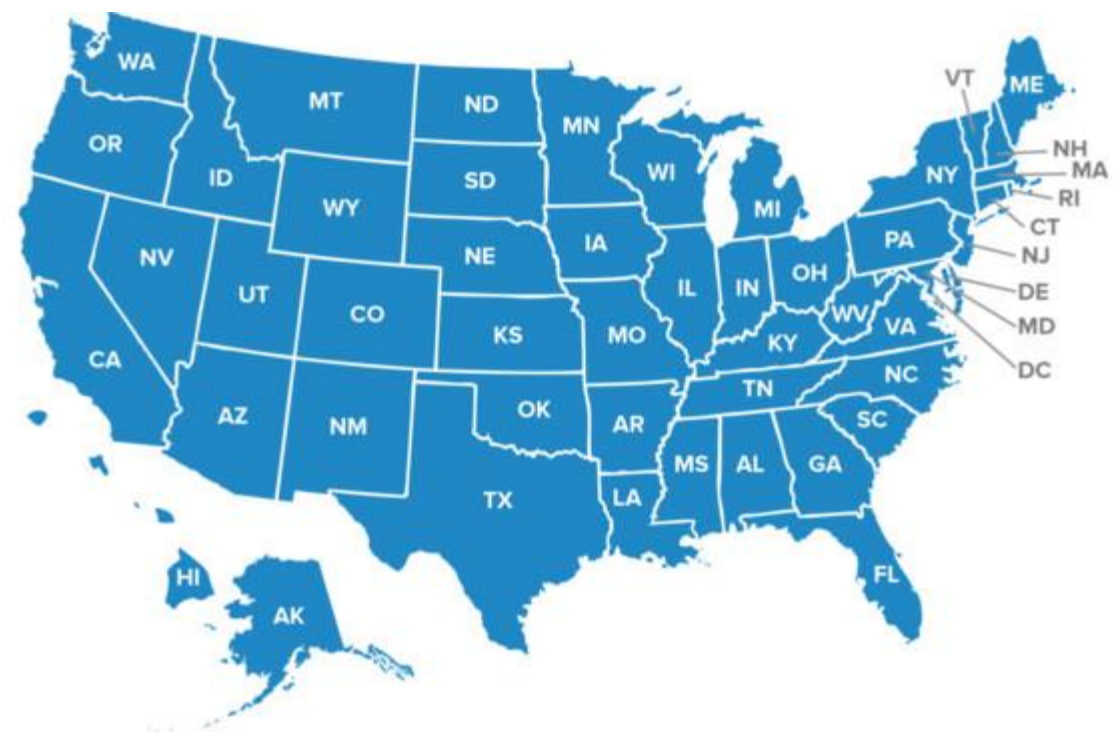

Forrás: usa.gov 
E szervezetek feladatai közé tartozik az állam területén dolgozó népegészségügyi szakemberek munkájának és továbbképzésének támogatása, valamint számos prevenciós szolgáltatás biztosítása. Az állami egészségügyi minisztériumok múködését 50\%-ban szövetségi szintű alapokból finanszírozzák, a múködési forrás másik fele tagállami alapokból és egyéb bevételekből tevődik össze.

\section{KÖZÖSSÉGI SZINTEN MŰKÖDŐ SZERVEZETEK}

Közösségi szinten a helyi egészségosztályok (LHD: Local Health Department) feladata a népegészségügyi szolgáltatások biztosítása a lakosság számára. Jelenleg 2533 LHD múködik az országban, melyek nagyobbrészt egy-egy megye ellátásáért felelősek, amelyekhez néhány tízezer-százezer fős populáció tartozik, elenyésző esetben viszont egymillió főt meghaladó térségért is felelősek. Az LHD-k által biztosított szolgáltatások és az alkalmazottak száma egyaránt illeszkedik a múködési területükhöz: alacsonyabb számú lakosságot az átlagnál kevesebb alkalmazottal és szűkebb szolgáltatási portfólióval látnak el, míg a magasabb számú lakosság számára az átlagosnál több szakértővel, szélesebb szolgáltatási portfóliót kínálnak. ${ }^{10}$

Az LHD-k irányítási módszerét tekintve négy különböző modell alakult ki a tagállamokban. 1. Helyi/ decentralizált rendszer: az államban az LHD-kat a helyi önkormányzatok vezetik és hozzák meg a pénzügyi döntéseket; 2 . Vegyes irányítási rendszer: az államban egyes LHD-kat a helyi önkormányzatok, más LHD-kat az Állami Egészségminisztérium vezet; 3. Állami/centralizált rendszer: az államban a LHD-k az Állami Egészségminisztérium szervezeti egységei, a pénzügyi döntéseiket is ez a szervezet hozza meg; 4. Megosztott irányítási rendszer: az államban az LHD-kat a helyi önkormányzatok és az Állami Egészségminisztérium közösen irányítja.

Az LHD-káltal nyújtott szolgáltatások meglehetősen széles körűek és egységenként változnak. Tevékenységeik között járványügyi, környezet-egészségügyi, betegségmegelőzési, egészségfejlesztési szolgáltatások egyaránt azonosíthatók, és részt vesznek az egészségtervek készítésében és megvalósításában. Feladatuk egyrészt az egészséges életmódra ösztönző programok, szolgáltatások biztosítása, a dohányzásról való leszokás támogatása. Számos LHD nyújt iskola-egészségügyi, lelki egészségfejlesz- tési, szájhigiénés, otthonápolási, alapellátási, anyaés gyermek egészségügyi, családtervezési szolgáltatásokat. Az LHD-k jelentős része végez szűrővizsgálatokat betegségekre (pl. szexuális úton terjedő betegségek, tuberkulózis), illetve a betegségek kockázati tényezőire vonatkozóan (pl. diabétesz, érrendszeri betegségek). E szervezetek egy része néhány szexuális úton terjedő betegség kezelésében is részt vesz. Az LHD-k felelősek továbbá a lakosság immunizálásáért, és a járványügyi, valamint környezet-egészségügyi feladataik ellátása érdekében laboratóriumi szolgáltatásokat is biztosítaniuk kell.

A szolgáltatások többségét az LHD-k saját személyi állományuk segítségével biztosítják. Általánosságban ugyanakkor elmondható, hogy az LHD-k közel fele legalább egy szolgáltatást kiszervez, azaz megvásárol más szolgáltatótól. Amíg a kisebb méretű, ötvenezer fő alatti területet ellátó - és emiatt kisebb költségvetésből gazdálkodó - szervezetek mintegy fele szervez ki legalább egy szolgáltatást, addig a félmillió fót meghaladó LHD-k háromnegyede él ezzel a lehetőséggel. A leggyakrabban kiszervezett szolgáltatás a laboratóriumi vizsgálat.

Egy LHD személyi állománya nagyban függ az ellátott terület nagyságától. A tízezer fő alatti területet ellátó LHD-k munkatársainak száma átlagosan 6 fö, a 25-50 000 fő közötti lakosságért felelős szervezetnél átlagosan 19 fö, a 100-250 ezer fős ellátási területtel rendelkező szervezetnél átlag 64 fő, míg a negyedmillió feletti populáció esetében átlagosan 230 fő szakember dolgozik az LHD alkalmazásában. Amíg a legkisebb (maximum 50 ezer főt ellátó) LHDkban ápolók, nővérek, környezet-egészségügyi szakemberek, adminisztrációs munkatársak és egy szakmai vezető dolgozik, addig a legnagyobb lakosságot ellátó LHD-k közel tízszer annyi ápolót, nővért, környezet-egészségügyi szakembert és adminisztrációs munkatársat, továbbá egészségfejlesztési szakértőket, dietetikusokat, statisztikusokat, informatikusokat, közgazdászokat, orvosokat és szakmai vezetőket alkalmaznak.

Az LHD-k költségvetése több forrásra támaszkodik és tekintettel az igen heterogén rendszerre, meglehetősen változó képet mutat. Összességében általában a helyi (megyei) források adják a legnagyobb arányt, de a tagállami finanszírozás is igen jelentős. A szövetségi rendszerből közvetlenül és közvetetten is kapnak finanszírozást, és ide érthető a Medicare és Medicaid rendszer által számukra nyújtott 
pénzeszközök is. Az LHD-k elfogadhatnak privát forrásokat is (pl. alapítványoktól, egyesületektől) és lehetőség van bizonyos díjak és esetenként büntetési tételek beszedésére is. Az egyéni hozzájárulás is előfordul, bár igen ritka.

Az LHD-k túlnyomó többsége partneri együttműködéseket köt, kapcsolatot tart több érintett szereplövel akár annak érdekében, hogy így biztosítsa szolgáltatásait, akár annak érdekében, hogy felügyelje azok működését. Külön kiemelendő, hogy az LHD-k egymással is partnerségben vannak, több mint felük megosztja egy másik LHD-vel az erőforrásait (pénzeszközök, humán erőforrás, berendezések). Az LHD-k külső partnerekkel való együttmúködéseit három fő kategóriába sorolhatjuk a szervezetek típusa szerint: egészségügyi szervezetek; közösségi szervezetek, illetve kormányzati szervek. A legtöbb LHD valamilyen módon együttmúködik a sürgőségi ellátókkal, mentőkkel és a helyi kórházakkal. Ugyancsak nagy arányban múködnek együtt az LHD-k a körzeti orvosokkal, közösségi egészségszolgáltatókkal, illetve mentális egészségközpontokkal. A közösségi partnerek közül szinte mindegyik LHD partnerségben van az iskolákkal, ugyanilyen magas arányban tartják a kapcsolatot a helyi médiával és civil szervezetekkel. Az LHD-k jelentős része kapcsolatot tart a civil szervezetekkel, egyházi szervezetekkel, egyetemekkel, főiskolákkal, illetve a helyi vállalkozásokkal. A kormányzati szervezetek közül az LHD-k együttmúködnek az igazságszolgáltatási rendszerrel, kapcsolatot tartanak a helyi fejlesztési tervekért felelős hatóságokkal, partnerségben vannak a közterületekért és parkokért felelős egységekkel valamint az építkezésekért és közlekedésért felelő szervezetekkel. Az együttműködés különböző módon valósul meg, például információcserében, rendszeres egyeztetésekben, írásos megállapodások megkötésében.

\section{Példa: New Jersey Állam Cape May Megyei Helyi Egészségosztálya}

Cape May megye New Jersey állam legdélebbi megyéje, lakosságszáma mintegy 95 ezer fö. Mindösszesen 16 önkormányzat múködik a megyén belül, ezek egy része egy-egy kisebb települést jelent, de bizonyos esetekben ez egy-egy nagyobb kerületet, körzetet jelent. A megye föleg a turizmusra épít, így a nyári időszakban a vendégforgalom igen erős, a vendégek száma akár a helyi lakosság 6-8-szorosát is elérheti. ${ }^{11}$

Az LHD által biztosított szolgáltatások között szerepel a rosszindulatú daganatokra irányuló prevenciós program, amely emlő-, méhnyak-, prosztata- és vastagbéldaganat-szűrést kínál a biztosítás nélküli lakosoknak, ezenfelül edukációs feladatokat is végeznek. Külön egysége az LHD-nak a közösségi egészségtervező csapat, amelynek tevékenységei között szerepel a partnerségek építése és az egészségkommunikáció. A szervezet feladata továbbá a vészhelyzeti (mint például hurrikán közeledése) felkészülés, ezzel kapcsolatban az LHD honlapja részletes információkkal szolgál a lakosság számára a vészhelyzet esetén szükséges teendőkről.

A családtervezési szolgáltatások körében a kívánt várandósság előtt javasolt egészségügyi szolgáltatások vehetők igénybe ( $p l$. anyai magas vérnyomás, cukorbetegség ellenőrzés), de az LHD ezen részlege alkalomszerűen információs napokat is szervez a közösség tagjai számára különböző helyszíneken. A környezet-egészségügyi egység a klasszikus hatósági feladatokat látja el, ideértve az élelmiszerbiztonságot is. Az LHD laborszolgáltatást is nyújt, egyéni és környezeti szinten, előbbi egészen széles körű (vérkép, vérkémia, vizelet, fertőző betegségek, immunológia, toxikológia), míg utóbbi a vízvizsgálatokra szorítkozik. A szervezet egészségfejlesztési programjai közé sorolható például a nagyon alaposan kidolgozott egészségnevelési program, amely általános és középiskolák számára kész óravázlatot tartalmazó programcsomagot kínál. Az LHD továbbá az egészséges étkezést támogató programokat is megvalósít, valamint tanácsadást és képzést biztosít a fertőző betegségek megelőzése területén.

\section{TANULSÁGOK A HAZAI NÉPEGÉSZSÉGÜGYI RENDSZER TOVÁBBFEJLESZTÉSÉHEZ}

Az Amerikai Egyesült Államokban a helyi kezdeményezések támogatása, önszerveződés és organikus fejlődési struktúrák mind megfigyelhetők, kiemelten a közösségi szinten, ahol változatos képet mutatnak az egészségfejlesztési szereplők. Tekintve az ország méretét és kultúráját, a rendszert kevésbé jellemzi az erős hierarchikus struktúra, minden funkciót és feladatot a legalacsonyabb múködési szinten igyekeznek ellátni, azonban a központi 
kormányzattól is kapnak szakmai és anyagi támogatást. A rendszerben számos intézet támogatja a humán erőforrás folyamatos fejlesztését a népegészségügyi szakemberek elméleti és gyakorlati képzésével. Az ország népegészségügyének fontos jellemzője továbbá, hogy épít a szervezetek közötti együttmúködésre és tudásmegosztásra. A helyi egészségosztályok tagállamonként eltérő múködési modellje alakult ki, azonban fontos tanulság az, hogy e szervezetek szolgáltatási portfóliója, valamint humán erőforrása igazodik az ellátott populáció nagyságához. Fontos tapasztalat, hogy a közösségi szinten itt is megjelenik az egészségtervezési funkció, amiben aktív szerepet kapnak a helyi egészségosztályok. Kiemelendő továbbá e szervezetek hálózatépítésben betöltött kulcsszerepe, aminek során együttmúködik, partnerségeket alakít ki az egészségfejlesztésben érdekelt közösségi szereplókkel. A helyi egészségosztályok munkáját támogatja egy szakmai ernyőszervezet, amely módszertani központként szolgáltatási protokollokat készít, elősegítve a népegészségügyi szolgáltatások minőségének fejlesztését és egységesítését. Tanulságos továbbá, hogy számos szervezet végez széles körű népegészségügyi kutatásokat, a Nemzeti Egészségügyi Intézetek tagintézményei egy-egy egészségprobléma területére specializálódtak.

A tanulmány az EFOP-1.8.0-VEKOP-17-2017-00001 Egészségügyi ellátórendszer szakmai módszertani fejlesztése projekt keretein belül készült.

\section{HIVATKOZÁSOK}

\footnotetext{
${ }^{1}$ GYEMSZI Informatikai és Rendszerelemzési Főigazgatóság. Tájékoztató országtanulmány az Amerikai Egyesült Államok egészségügyéről. 2014 https://era.aeek.hu/HolOrszag/csatolt/20140918_egyesult_kiralysag_2014.pdf Elérve: 2018.04. 04.

${ }^{2}$ Centers for Disease Control and Prevention: United States Public Health. Presentation. 2013

https://www.cdc.gov/stltpublichealth/docs/usph101.pptx Elérve: 2018. 04. 04.

${ }^{3}$ Mossialos E, Wenzl M, Osborn R, et al. International profiles of health care systems. 2015

http://www.commonwealthfund.org/ /media/files/publications/fund-report/2016/jan/1857_mossialos_intl_profiles_2015_v7.pdf?la=en Elérve: 2018.04.04.

${ }^{4}$ National Association of County and City Health Officials: Annual Report. 2015

https://www.naccho.org/uploads/downloadable-resources/2015-NACCHO-Annual-Report.pdf Elérve: 2018. 04. 04.

${ }^{5}$ Alexander BD, Evans JL, Lippincott EB. Fundamentals of Medicare and Medicaid Reimbursement. Institute on Medicare and Medicaid Payment. 2014

${ }^{6}$ Preston CM, Alexander M. Prevention in the United States, Affordable Care Act. J Prev Med Public Health. 2010 Nov;43(6):455-8.

https://www.jpmph.org/upload/pdf/jpmph-43-455.pdf Elérve: 2018. 04. 04.

${ }^{7}$ National Prevention Council: National Prevention Strategy. America's plan for better health and wellness. 2011 https://www.surgeongeneral.gov/priorities/prevention/strategy/report.pdf

${ }^{8}$ Rice T, Rosenau P, Unruh L, Barnes AJ. Health system review - United States of America. Health System in Transition. 2013

http://www.euro.who.int/_data/assets/pdf_file/0019/215155/HiT-United-States-of-America.pdf Elérve: 2018. 04.04. ${ }^{9}$ National Institutes of Health: Report of the Director National Institutes of Health. 2012 https://report.nih.gov/pdf/NIH_Biennial_Report_2012.pdf Elérve: 2018. 04. 04.

${ }^{10}$ National Association of County and City Health Officials: National profile of Local Health Departments. 2016 http://nacchoprofilestudy.org/wp-content/uploads/2017/10/Summary_Report_Oct2017_Final.pdf Elérve: 2018. 04. 04.

${ }^{11}$ Cape May County Public Health Community. Linking people to needed community health services. 2013
} 